\title{
The 2Rs - Respect and Responsibility: The Case of Australian Muslim Girls
}

\author{
Nahid Afrose Kabir
}

\begin{abstract}
The citizenship debate involves respect and responsibility, and these can be achieved through collective action. Though many members of disadvantaged groups sympathise with the goals of social movements fighting injustice against their in-group (own community) or out-group (wider society) often only a small percentage of them actually participate in collective activities staged to realise these goals (Louis 2009; Sturmer and Simon 2009). In this paper I discuss the case of Australian Muslims girls who in their home environment respect the family values and carry out certain responsibilities assigned to them. By family values, I mean respect for elders, performing religious duties, for example, offering prayers, and fasting during the month of Ramadan, helping mother in the kitchen and looking after their siblings. In the wider society, Muslim girls attend schools, do part-time jobs and obey Australian values of fair-go, tolerance and multiculturalism ceremoniously (see Kabir 2008). However, I question in this paper, whether their family and the wider society are working collectively to fulfil their responsibility towards these girls. I discuss the interview responses of 39 Muslim girls (15-18 years) living in Sydney and Perth. I examine pertinent cases within the framework of relevant academic literature, and argue within the social, religious and cultural context. The issues within the family domain are inter-twined within Islamic religious-cultural arguments, whereas the issues in the public domain are argued on cultural conflict between the Muslims and the wider society. With both arguments I show how some Muslim girls negotiate their identity, and suggest their bicultural identity is assisting them to keep a positive attitude in their everyday life. Finally, I advocate that collective action from both the Muslim and the wider community is vital for the well-being of these girls.
\end{abstract}

\section{Introduction}

Individuals, families, and communities must take collective responsibility for their own well-being. Children are expected to respect the values of their families, schools, and wider community, and parents are responsible for ensuring that their children attend schools and are supported in their learning. In the broader context, citizens are expected to support each other irrespective of their ethnic background and religion. My research on Muslims in Australia since late 1998 shows that in general Muslims and non-Muslims have respected each other. In this paper I discuss certain gender issues pertaining to both Muslims and the wider community, which is gender specific. I observe that if we address the issues collectively as one Australian community more respect and responsibility can 
be achieved. I have framed the paper within the context of private and public domains. By private domain, I mean that there are certain issues that young women face within their cultural and religious boundaries, while public domain is more specific to the wider society that addresses majority-minority relations. In the next sections, first, I examine some literature relevant to this paper. Second, I outline the research methodology. Third, I discuss certain cultural restrictions in the private domain. Fourth, I consider the societal resistance in the public domain. Finally, in the conclusion, I put forward some suggestions on our collective responsibility.

\section{Literature review}

There is a burgeoning literature on this topic, however, I am discussing that literature (and media discussions) that has specifically pointed out Muslim women's dilemma both in private and public domain. For example, in a Canadian study, Khan identifies two factors - family and community pressures - that Muslim women have to deal with in the private domain. Muslim women usually live in extended families, where all children respect their elders, and where women live under the unquestioning authority of their religion (Khan 2002: 14-15). Muslim women are also expected to adhere to male community leadership. Khan points out some women do resist sexism and male domination; at the same time they are aware that their resistance could strain or damage their relationships with families and communities, leaving them vulnerable in a society where they face not only sexism but also racism (Khan 2002: 14-15).

Khan (2002: 14-15) observes that although frequently the structure of a Canadian Muslim family is patriarchal and conservative, community spaces are important, for they tend to replicate and replace the kinship networks many immigrants have left behind. Some male and female members uphold conservative ideals of a religious patriarchal community. Yet for other women, the communities have become prisons where the security of these communities blocks opportunities available in the larger society, such as education, employment and more freedom. However, if women move toward those perceived freedoms, there is a price to pay: They often face exclusion from their communities as well as discrimination from the mainstream. In other words, if they stay within their 
communities, they endure increasingly less control over their mobility and sexuality. Although the Muslim communities in Western nations are diverse racially and culturally, the heterogeneous and, at times, contradictory voices get subsumed under the rubric "the Muslim community” (Khan 2002: 19).

In the British case, in the private domain Tomlinson (1984: 28) finds that the majority of Pakistani and Bangladeshi settlers in Britain are Muslims, and conflicts between the Muslims and mainstream British do arise. Arguably this is more so in 2008, with a worldwide resurgence of Islamic traditions challenging Western secular values. Tomlinson (1984: 28) points out that the major points of conflict concern the education of girls, the place of women in society, and the ways Muslim girls are expected to behave. The issue of arranged marriages, particularly, has provoked anxiety and often criticisms from nonMuslims.

In the Australian context, Bouma and Grace-Govan (2000: 163) note that some newlyarrived migrant Muslim women felt the impact of immigration quite keenly. While men had to go out and learn enough English to get jobs, "some women, felt isolated, unable to deal with the strange language and strange ways of Australia”. The lack of language and friends left them confused, frightened to go out in public and feeling disorientated. On the other hand, Yasmeen (2002) observes that migrant Muslim women with good English skills and professional experience, who occupied senior managerial positions in their countries of origin, often have found it difficult to secure equivalent jobs in Australia. Their overseas experience was not recognised by the Australian labour market. Both Muslim men and women have either resigned themselves to living on the stipend provided by the social security system or opted for jobs that are unrelated to their professional qualifications. The ensuing frustration has obviously created economic problems and sometimes domestic violence in the family, where women suffer the most. Also in the Australian context, Northcote et al. (2006) examined 38 refugee women of Iraqi, Afghan and Sudanese backgrounds in Perth, and conclude that both internal 'ethnic' factors (cultural restrictions, domestic violence) and external societal factors (discrimination, racism) are jointly involved in perpetuating a cycle of isolation for 
Muslim refugee women. Moreover, in the private domain, Joumanah El Matrah, the manager of the Islamic Women's Welfare Council of Victoria notes that though some women remain victims of sexual violence in Muslim communities, they keep silent. El Matrah states (ABC 2005):

I think it's politically dangerous in the sense that one always risks the possibility of being completely alienated from the community, and having one's political power undermined. Is it dangerous in a physical way? I'm not sure yet. We haven't had any examples of that at all, but there are plenty of examples where women have been isolated from the general community of community leaders, if you like. That strategy is still used by Muslim men.

Similarly, in the public domain El Matrah (ABC 2008) observes that some Muslim women faced racism but the wider society was slow to respond to their call:

....women have talked about ringing the police for assistance when they've been assaulted, and the police haven't shown up, and clearly the police should have shown up. And I'm not entirely sure we can do anything about it, other than improve community awareness and keep doing anti-racism work and those sorts of strategies, because it's not reasonable, and indeed many Muslim women don't have the view that the police should come and hunt down that sort of perpetrator. But it does nonetheless leave them to kind of deal with those assaults on their own.

Various studies in Western democratic countries (Haddad et al. 2006; Poynting and Mason 2006; Kabir 2007a; Human Rights and Equal Opportunity Commission, 2004; 2008) suggest that the needs and concerns of Muslim migrants have become more acute than other migrants, particularly since 2001 when extremist militant Muslims have embarked on acts of terrorism and evoked widespread xenophobia in Western societies. Respect for Muslim women and the collective responsibility of the communities towards these women is the theme of this paper. Therefore, it is important that Muslim women needs are addressed through a collective effort, both by the Muslim and the wider community. 


\section{The research methodology}

The data for this study comprise responses from in-depth, face-to-face, semi-structured interviews of 39 Muslim female students (15-18 years old) of diverse backgrounds who attended two schools in Sydney and one school in Perth in the period 2006-2007. The participants were: 10 Australian-born girls and 15 overseas-born girls in Sydney; 2 Australian-born girls and 12 overseas-born girls in Perth. I asked the participants about their lives, including early school memories, family members, parents’ work status, students' part-time work, sporting activities, music, entertainment and cultural interests, together with their hopes, ambitions and dreams. There were 30 questions relating to their life story. For example, I asked them about their early memory of school, and the best memories of school. What were their hobbies? How they used their leisure time? Did they watch sports? and were they fond of music? I asked them if music contributed positively to youth development. I also asked them if they had friends and whether they had boyfriends. I asked them about their cultural and religious celebrations, and how they would define their identity/national identity or their sense of belonging. There were questions such as what was meant by "an Australian” and "un-Australian”. I also asked whether as Muslims they experienced any challenges since 9/11 and the 7/7 London tragedy. If so, could they give any example. Finally, I asked them about their hopes and dreams and how would they contribute to the society.

I have employed the grounded theory method (Glaser and Strauss 1967). Grounded theory is a type of qualitative method. It is a non-statistical method which describes a methodological approach that is about "letting the data speak" and not imposing preformed hypotheses. The goal of this research was to gain a better understanding of the participants through their life stories, their hopes and aspirations. Most importantly, it was designed to allow respondents to speak issues important to them. I have employed the constructivist method of interpretation (Charmaz 2006). Constructivism is defined as an educational approach that emphasises the researcher's unique ability to make their own meaning out of information (interviews). So through the participants' interviews, I have contextualised their need, concerns, stress, identity, hopes and aspirations. I then 
tried to access the roles and responsibility of the community as a whole toward these young women.

Table 1 below shows the pattern of the students' daily lives. It shows all participants both overseas and Australian-born students in Sydney and Perth enjoyed music, sports, and their traditional cultural and religious celebrations. Only 5 girls (2 Australian-born and 3 overseas-born) in Sydney had a part-time job. In Perth, only 1 Australian-born girl had a part-time job. Having a boyfriend was considered a "taboo" by the participants. However, 4 Sydney girls (2 Australian-born and 2 overseas-born) confessed that they had boyfriends, while 2 girls (1 Australia-born and 1 overseas-born) girls in Perth spoke of their boyfriends. On the topic of racism, all girls believed that visible Muslim women who wore the hijab were vulnerable to racism, while 2 girls in Sydney and 1 in Perth encountered racism. It was encouraging to see all participants were hopeful of their future in Australia.

\section{Table 1: Summary of responses}

\begin{tabular}{|c|c|c|c|c|}
\hline Questions & Responses & Responses & Responses & Responses \\
\hline $\begin{array}{l}\text { Brief Life } \\
\text { stories }\end{array}$ & $\begin{array}{l}10 \text { Australian- } \\
\text { born Sydney } \\
\text { girls }\end{array}$ & $\begin{array}{l}2 \text { Australian- } \\
\text { born Perth } \\
\text { girls }\end{array}$ & $\begin{array}{l}15 \\
\text { overseas-born } \\
\text { Sydney girls }\end{array}$ & $\begin{array}{l}12 \\
\text { Overseas-born } \\
\text { Perth girls }\end{array}$ \\
\hline $\begin{array}{l}\text { Practice of } \\
\text { religion, } \\
\text { culture and } \\
\text { tradition. }\end{array}$ & $\begin{array}{l}\text { Ramadan and } \\
\text { Eid } \\
\text { celebrations \& } \\
\text { traditional } \\
\text { celebration \& } \\
\text { music }\end{array}$ & $\begin{array}{l}\text { Ramadan and } \\
\text { Eid } \\
\text { celebrations \& } \\
\text { traditional } \\
\text { celebration \& } \\
\text { music }\end{array}$ & $\begin{array}{l}\text { Ramadan and } \\
\text { Eid } \\
\text { celebrations \& } \\
\text { traditional } \\
\text { celebration \& } \\
\text { music }\end{array}$ & $\begin{array}{l}\text { Ramadan and } \\
\text { Eid } \\
\text { celebrations \& } \\
\text { traditional } \\
\text { celebration \& } \\
\text { music }\end{array}$ \\
\hline $\begin{array}{l}\text { Opposite sex } \\
\text { friends }\end{array}$ & $\begin{array}{l}\text { Not allowed to } \\
\text { have opposite } \\
\text { sex friends. } 2 \\
\text { girls have } \\
\text { boyfriends }\end{array}$ & $\begin{array}{l}\text { Not allowed to } \\
\text { have opposite } \\
\text { sex friends. } \\
1 \text { girl has a } \\
\text { boyfriend. }\end{array}$ & $\begin{array}{l}\text { Not allowed to } \\
\text { have opposite } \\
\text { sex friends. } 2 \\
\text { girls have } \\
\text { boyfriends. }\end{array}$ & $\begin{array}{l}\text { Not allowed to } \\
\text { have opposite } \\
\text { sex friends. } \\
1 \text { girl has a } \\
\text { boyfriend. }\end{array}$ \\
\hline $\begin{array}{l}\text { Work/part- } \\
\text { time job }\end{array}$ & $\begin{array}{l}1 \text { worked in } \\
\text { dad's shop, } 1 \\
\text { worked at } \\
\text { department } \\
\text { store }\end{array}$ & $\begin{array}{l}1 \text { girl worked } \\
\text { in a restaurant }\end{array}$ & $\begin{array}{l}1 \text { girl worked } \\
\text { in a restaurant, } \\
1 \text { in customer } \\
\text { service. } 1 \\
\text { worked at the } \\
\text { hair dresser }\end{array}$ & None \\
\hline
\end{tabular}




\begin{tabular}{|c|c|c|c|c|}
\hline Music & $\begin{array}{l}\text { Rap, Hip Hop, } \\
\text { James Blunt, } \\
\text { West Life, } \\
\text { Heavy Metal, } \\
\text { Rock }\end{array}$ & Matchbox 20 & $\begin{array}{l}\text { R \& B, } \\
\text { Shakira, } \\
\text { Mariah Carey, } \\
\text { Delta } \\
\text { Goodrem, } \\
\text { Backstreet } \\
\text { Boys }\end{array}$ & $\begin{array}{l}\text { Chris Brown, } \\
\text { Nelly Furtado, } \\
\text { James Blunt, } \\
\text { R\&B, pop, }\end{array}$ \\
\hline Sports & $\begin{array}{l}\text { Soccer, } \\
\text { running, basket } \\
\text { ball }\end{array}$ & $\begin{array}{l}\text { Soccer and } \\
\text { basket ball }\end{array}$ & $\begin{array}{l}\text { Badminton, } \\
\text { volley ball }\end{array}$ & Volley ball \\
\hline Racism & $\begin{array}{l}\text { All said that } \\
\text { the hijab } \\
\text { women are } \\
\text { vulnerable to } \\
\text { vilification } \\
\text { All participants } \\
\text { were critical of } \\
\text { unbalanced } \\
\text { media } \\
\text { reporting }\end{array}$ & $\begin{array}{l}\text { All said that } \\
\text { the hijab } \\
\text { women are } \\
\text { vulnerable to } \\
\text { vilification } \\
\text { All } \\
\text { participants } \\
\text { were critical of } \\
\text { unbalanced } \\
\text { media } \\
\text { reporting }\end{array}$ & $\begin{array}{l}\text { All said that } \\
\text { the hijab } \\
\text { women are } \\
\text { vulnerable to } \\
\text { vilification. } \\
2 \text { girls who } \\
\text { wear hijab } \\
\text { encountered } \\
\text { racism } \\
\text { All } \\
\text { participants } \\
\text { were critical of } \\
\text { unbalanced } \\
\text { media } \\
\text { reporting }\end{array}$ & $\begin{array}{l}\text { All said that } \\
\text { the hijab } \\
\text { women are } \\
\text { vulnerable to } \\
\text { vilification. } \\
1 \text { girl } \\
\text { encountered } \\
\text { hijab } \\
\text { discrimination } \\
\text { All participants } \\
\text { were critical of } \\
\text { unbalanced } \\
\text { media } \\
\text { reporting }\end{array}$ \\
\hline $\begin{array}{l}\text { Hopes and } \\
\text { aspirations }\end{array}$ & $\begin{array}{l}\text { Doctor, chef, } \\
\text { forensic } \\
\text { scientist, } \\
\text { journalist, } \\
\text { history teacher, } \\
\text { computer } \\
\text { work, } \\
\text { hairdressing, } \\
\text { child care, Uni } \\
\text { teacher }\end{array}$ & $\begin{array}{l}\text { nurse, } \\
\text { cartoonist, } \\
\text { interior } \\
\text { decorator }\end{array}$ & $\begin{array}{l}\text { Hair dresser, } \\
\text { Interior } \\
\text { decorator, } \\
\text { multimedia } \\
\text { developer, } \\
\text { accounting, } \\
\text { business, } \\
\text { engineering, } \\
\text { modelling, } \\
\text { lawyer }\end{array}$ & $\begin{array}{l}\text { Fashion } \\
\text { designer, } \\
\text { pharmacist, } \\
\text { health } \\
\text { sciences, } \\
\text { medicine, } \\
\text { lawyer }\end{array}$ \\
\hline
\end{tabular}

In the next section, I discuss the participants' experience in their private domain. I examine their cultural values, and some of the constraints faced by them. 


\section{Private domain: Cultural values}

In the American context, Haddad et al. (2006:14) state that a primary challenge facing Muslim women and their families is that of raising children. Irrespective of the patriarchal society, both mother and father have the same concern of raising their children in the Islamic way. They struggle with issues such as keeping their children insulated from what the parents perceive to be dangerous Western secular values; at the same time they acknowledge their children's citizenship in the West and want to prepare them to be able to live their lives in a Western culture. In Germany (Blaschke and Sabanovic 2004: 59) a survey shows that generally Muslim women accept the following rules: women are not allowed to break up a marriage; pre-marital sex is prohibited; the females should be covered down to the ankles and a headscarf should cover their hair; and women should avoid engaging in the public realm of life.

In this study, all participants understood their family expectations and respected their family values. Of the 25 Sydney girls, two girls’ parents were divorced, 12 fathers were unemployed, one father was deceased, and the other 12 fathers had blue-collared jobs; but only one mother was employed. Of the 14 Perth participants, three parents were divorced, three fathers had white-collared jobs, four fathers had blue-collared jobs and the other 7 fathers were unemployed; here two mothers were employed. Some parents also had ill-health. The newly arrived overseas-born refugee girls in both locations appeared to be engaged more with home duties, for example, cooking, washing, ironing, looking after their siblings, and one was a bread winner as her both parents were ill. These girls were also struggling in the schools to achieve well with their relatively limited English skills. As one girl commented, "New people, new language, new studying stuff...I have science which I haven't studied for 3 years, and my mum she expects me to become first in everything”.

From my research work I have noticed that the general expectation of home duties from daughters is common among the new arrivals. However, sometimes, the old immigrants, particularly from the working class prefer to keep their daughters occupied in home duties so that after their marriage they could give a good name to their family. And the 
pressure from parents that their children achieve high in school is generally common in the Asian families (both Muslim and non-Muslims).

For this study, when we discussed cultural values and traditions, all participants said that they observed the month of fasting (Ramadan), enjoyed Muslim religious festivals, Eid ul Fitr and Eid ul Azha and their traditional cultural celebrations, especially weddings. As discussed earlier, the topic of boyfriend is considered a "taboo" in the Muslim families. Since my research was on young Australian Muslim identity, I had to ask question on friends/friendship/boyfriends which is a part of youth culture. With the exception of six girls, all abided by their family expectation that having a boyfriend was unacceptable. As a Somalian-born girl, Sufia commented:

No, that's haram (forbidden in Islam). You're not allowed to have boyfriends. And again why do you want to have a boyfriend? You know we have to study to get to university and after you become something you can think of you know, having someone, but not now.

An Australian-born student of Syrian origin Mehjabeen said:

Actually, it's not actually a boyfriend, but I told my mum that I like this person, and he likes me as well, and he will come and ask for my hand or engagement so she agrees, but as for going out with him without engagement or anything, it's not in our culture.

A couple of girls said that they had boyfriends but they were secretive about it because it was not permitted by the parents. An Australian girl of Lebanese background, Safa, said about her family's reaction if she had a boyfriend:

My friends have boyfriends. They know it's wrong and acknowledged that it's wrong but I think it's part of today's society. People are easily influenced. However, I don't have a boyfriend. I'd be out living on the street I think! I wouldn't have parents; they'd disown me!

An Australian-born Muslim student, Rabia, commented about her religion and the need to be secretive when it comes to non-Muslim boyfriends: 
Well I'm Muslim, but only by name, I mean by blood, or name, whatever... it's confusing. Yeah but (boyfriends), it's still against my religion. You're maybe meant to look at it in an indirect direction. Like I talk to them (Muslim boys) and go out with them, it's really bad. My parents know, but my older brothers took it harsh, like really bad. They don’t know all my movements! Very tough time, but I rarely get caught.

A Pakistan-born girl, Bilkis, said that she can't marry the boy she loves even though he is a Pakistani Muslim but he belongs to a different caste. She fears:

I am from the Jat caste and my boyfriend is from the Rajput caste. My father would get angry. If I have any relation with any guys he won't like it; I think because of the culture. My father wants me to marry his nephew instead and wants to bring him to Sydney.

In the British context, Jacobson (1998) finds some Pakistani Muslims are keen to arrange the marriage of their children with their cousins. Otherwise, the marriage within the caste remains a priority. However, marrying a cousin is not exclusively a Pakistani practice. It is prevalent among other Muslim ethnic groups, but it is not widely practiced.

In Australia (Harris 2005, p.1), official reports have confirmed that a dozen girls, all aged under 18, have approached the Australian embassy in Beirut for help. They had been sent against their wishes to Lebanon. A 14 year-old Australian girl said that she was promised a holiday in Lebanon by her father, but was forced to marry an older man who imprisoned her in his home (Harris 2005, p.1). The Victorian Arabic Social Services manager in Melbourne, Leila Alloush, says many arranged marriages, especially among older couples, are loving and successful. But if they break down, the suffering can extend beyond the couple in question. Families on both sides, often friends beforehand, are torn apart in communities that frown on divorce (Harris 2005, p.1). Thus, within the concept of 2Rs (respect and responsibility), some Muslim girls tend to override the expectations of not having a boyfriend. On the other hand, some parents ignore the complication of forced marriages and the fact that excessive home duties would be detrimental to the children's progress in schools. 


\section{Public domain: Societal resistance}

Almost all the 39 students in this study said that the world has changed for the Muslims since September 11, 2001. Some girls who do not look visibly different from mainstream Australians (that is who do not wear hijabs) said they personally did not encounter any vilification from the wider society but their friends and relatives who wear the hijabs have been vilified in their presence. An Australian girl of Lebanese background, Safa, commented:

There has been an instance, I can't recall with my family, but I remember my friend, she comes to this school, she wears the hijab (headscarf), she said...well she's walking past I think, someone that was drinking beer, and he swore at her and chucked a bottle of beer at her!

A Pakistani-born girl, Nargis, thought that the hijab was a barrier to obtaining work:

I had an interview at a fast food shop in Sydney and like me and the other girl, and she wasn't wearing scarf, and they just gave her job. Maybe, I don't know, but I felt they didn't give me maybe because of scarf. But I think for the job or for the money, I'm not going to take off my scarf.

A Muslim girl of Bangladeshi origin, Shoma, said:

I had an interview at a fast food shop in Perth. I was asked if I would take off my hijab at work. My answer was "No". So I did not get the job. I also gave a job interview for a position at a departmental store. I did not get a job. These jobs do not need any special skills. Still I did not get the job. This is very stressful.

Shoma thought the lack of balanced journalistic reporting is creating such tension in the society:

I find that a lot of the things that I come across on TV, or on a newspaper, they are not only negative, but they do in a way contribute to the negativity that some Muslims face in the community. One of the biggest challenges 
they face today is to take it as a responsibility in fair reporting in the media. And most of the times it's very important to be careful of what sort of image we are broadcasting to the public because at the end of the day they do have a very big impact on the public.... What we need to realise, especially journalists when they are reporting, that as Australians our differences are not there to divide us, they're there to make our society and our community a stronger one.

Australia has experienced an upsurge of racially and culturally based attacks on visible Muslims, particularly women who wear the hijab. A survey of 186 Arab and Muslim Australians in Sydney and Melbourne conducted in 2003 recorded that 87 per cent of Muslim respondents had experienced racism, abuse or racist violence since 9/11, with three-quarters stating that they have experienced "a bit more” than prior to 9/11 and 37 per cent “a lot more”. After 9/11, the report Ismaع (HREOC 2004) found that people identifiable as Arab or Muslim by their dress, language, name or appearance were abused, threatened, spatted on, attacked with eggs, bottles, cans and rocks, punched and bitten. Drivers were run off the road and pedestrians were run down on footpaths and in car parks. People reported being fired from their jobs or refused employment or promotion because of their race or religion. Children were bullied in school yards. Women have been assaulted in shopping centres. Private homes, places of worship and schools were vandalised and burnt. Muslim and Arab-Australians were labeled as “Terrorist” "Dirty Arab” "Bloody Muslim” “Bin-Laden”, and "Illegal immigrant”(see Human Rights and Equal Opportunity Commission 2004,p. III; Poynting and Mason: 2006, pp.365-391, see also Kabir 2005; Kabir 2007a; Kabir 2007b).

$H i j a b$ has been unacceptable to some members of the wider community, but the niqab (face veil) is rejected by most members of the wider community. In Perth, a Muslim mother of six children who wore a niqab was repeatedly punched and slapped while her young children slept nearby when several men crashed through the front door of her house. The men could not be charged under the new racial hate laws because the attack happened in a home, not a public place (Lampathakis 2005, p. 7). Apparently, the woman has now abandoned her niqab. 
In the job market, many Australian-born Muslim women are disadvantaged. In 2006, 12.1 per cent Australian-born Muslim women were unemployed compared to 4.2 per cent of their Christian female counterparts (ABS). It is not known whether Muslim women prefer home duties, or whether their visibility (Islamic attire) or Muslim names are barriers to employment. In this study, out of 39 mothers, only three were employed. In another publication (Kabir 2007b), I found that most Muslim women were home makers.

\section{Conclusion}

A report on Muslim women in Australia (HREOC 2008) found that the generation gap between young people and their parents has been widened due to external factors. The younger generation often internalise their feelings of resentment at the wider society's treatment towards their mothers and sisters. Consequently, these young Muslims find it difficult to help their mothers cope. Also the mothers try to protect their daughters from vilification of the wider society and therefore, impose more restrictions on their daughters' movement. On some instances, parents ask their sons to be protective of their daughters when they go out. This over-protectiveness could lead to increasing passivity in women who appeared increasingly as the "other" both in the private and public domain. This then creates tensions between mothers and daughters (HREOC 2008, p. 20).

In this study, of the 39 Muslim participants, some are newly arrived refugees who are still coping with adjusting to the new environment, home duties and English skills. The Islamic values of not having opposite sex friends or relationships are accepted by most of the participants. The experience of racism and unbalanced media reporting were expressed by all students (see Table 1; also see Shoma’s interview).

These youth are in a period of transition to adulthood, which is influenced by social, cultural and economic surroundings. In the case of Australian Muslims, youth are influenced by ethnic, Islamic and western surroundings. Economically, most of these students belonged to the blue-collar group. With the exception of three women, all the participants' mothers were housewives, and some fathers were unemployed. 
A common characteristic of the Muslim girls was that they maintained a bicultural identity (Table 1). They defined themselves as Lebanese-Australians, or BangladeshiAustralians or Muslim-Australians. But they were mostly fond of Western music. For example, they listened to R\&B, Tupac, Mariah Carey, Usher, West Life, Missy Higgins and Delta Goodrem. Some read books by authors such as James Patterson. Some loved their school studies. Only one student was involved in debating and a few loved sports in school. A few students who worked in mainstream stores or shops appeared to have integrated well into the wider society and were confident in both cultures. Therefore, in spite of the concerns of home, school and society, the participants spoke about their connections to music, reading, sports, debate and work. Perhaps, through these connecting factors they are in the process of negotiating a balance within their cultural identity and family expectations.

By upholding the views of the participants of this study I aimed to emphasise collective action. As discussed, young Muslim girls encountered stress both in the private and public domain. Newly arrived migrant girls appeared to have more duties at home, and more expectations from parents and schools for high achievement. Therefore, it should be the responsibility of the school staff members and youth workers to be aware of the cultural circumstances of Muslim girls. They need to boost the students' confidence by improving their communication skills. A youth forum hosted by Muslim female youth workers would unveil some of the issues the Muslim students are confronting. There needs to be more dialogue within the Muslim community addressing issues such as forced marriages. There should more conversation between the parents and children, particularly mother and daughters to avoid hostility in the family.

Australia has brought in tough laws that could see people who traffic in young girls overseas for forced marriages jailed for up to 25 years (Mercer 2005). However, there is also a need for some tough state and federal religious vilification laws to provide protection for Muslim women who wear hijabs. Muslim families should encourage higher education for women. Muslim female social workers should work at the grass root levels to reach the diasporic community. The high unemployment of the Australian 
Muslim girls should also be addressed by both the Muslim community and the wider community. If a woman wants to remain a homemaker her wish should be respected. But if she wants to seek outside employment, opportunities should be provided both by the family members and the society.

\section{Acknowledgement}

I express my sincere gratitude to all the interviewees for this study. I thank the principals and staff of the schools for making this survey possible. I convey my thanks to the reviewers for their constructive comments. This research has been funded by the Edith Cowan University.

\section{References}

ABC Radio National 2005, The Religion Report: "Muslim Women in Australia”, 26 January. Online http://www.abc.net.au/rn/talks/8.30/relrpt/stories/s1290321.htm Accessed 12 November 2009.

ABC Radio National 2008, The Religion Report: "Muslim Women and Racism in Victoria”, 17 December, Online, http://www.abc.net.au/rn/religionreport /stories/2008/2447404.htm Accessed 12 November 2009.

Australian Bureau of Statistics, Census of Population and Housing, 2006.

Blaschke, J. and Sabanovic, S. 2004, "Multi-level Discrimination of Muslim Women in Germany", in Blaschke, J. ed., Multi-level Discrimination of Muslim Women in Europe, $2^{\text {nd }}$ Revised Edition, Edition Parabolis, Berlin.

Bouma, G. and Brace-Govan, J. 2000, "Gender and Religious Settlement: Families, hijabs and identity, Journal of Intercultural Studies, vol. 21, no. 2, pp. 159-175.

Charmaz, K. 2006, Constructing Grounded Theory: A Practical Guide through Qualitative Analysis, Sage publications, London.

Glaser, B. and Strauss, A. 1967, The Discovery of Grounded Theory: Strategies for Qualitative Research, Aldine, Chicago.

Jacobson, J. 1998, Islam in Transition: Religion and Identity among British Pakistan Youth, Routledge Curzon, London.

Haddad, Y., Smith J. and Moore, K. 2006, Muslim Women in America: The Challenge of Islamic Identity Today, Oxford University Press, Oxford.

Harris, T. 2005, “Australia: Early and Forced Marriages”, 2 August, http://www.wluml. org/english/newsfulltxt.shtml?cmd\%5B157\%5D=x-157-308734 Accessed 3 June 2008. 
Human Rights and Equal Opportunity Commission HREOC 2004, Ismaع - Listen: National Consultations on Eliminating Prejudice against Arab and Muslim Australians, HREOC, Sydney.

Human Rights and Equal Opportunity Commission, HREOC 2008, Living Spirit: A Dialogue on Human Rights and Responsibilities, HREOC, Sydney.

Kabir, N. 2005, Muslims in Australia: Immigration, Race Relations and Cultural History, Routledge, London.

Kabir, N. 2007a, "The Predicament of Australian Muslim Women in the Pre-and Post9/11 Era”, Islamic Studies, vol. 46, no.2, pp. 241-264.

Kabir, N. 2007b, "What Does it Mean to be Un-Australian: Views of Australian Muslim Students in 2006”, People and Place, vol.15, no. 1, pp. 62-79.

Kabir, N. 2008, “Are Young Muslims adopting Australian Values”, Australian Journal of Education, vol. 52, no.3, pp. 229-241.

Khan, S. 2002, Aversion and Desire: Negotiating Muslim Female Identity in the Diaspora, Women's Press, Toronto.

Lampathakis, P. 2005, “Muslim Family’s Terror in Race Attack”, The Sunday Times, 30 October, p. 7.

Louis, W. R. 2009, “Collective Action-and Then What?”, Journal of Social Issues, vol. 65, no. 4, pp.727-748.

Mercer, P. 2005, “Australia Acts on Forced Marriage”, BBC News, 3 August, http://news.bbc.co.uk/1/hi/world/asia-pacific/4740871.stm, Accessed 3 June 2008.

Northcote, J. Hancock, P. and Casimiro, S. 2006, "Breaking the isolation cycle: The Experience of Muslim Refugee Women in Australia”, Asian and Pacific Migration Journal, vol. 15, no. 2, pp. 177-199.

Poynting, S. and Mason, V. 2006, "Tolerance, Freedom, Justice and Peace? Britain, Australia and Anti-Muslim Racism since 11 September 2001”, Journal of Intercultural Studies, vol. 27, no.4, pp. 365-391.

Stürmer, S. and Simon, B. 2009, "Pathways to Collective Protest: Calculation, Identification, or Emotion? A Critical Analysis of the Role of Group-Based Anger in Social Movement Participation”, Journal of Social Issues, vol. 65, no. 4, pp. 681705.

Tomlinson, S. 1984, Home and School in Multicultural Britain, Batsford Academic and Educational, London.

Yasmeen, S. 2002, “Muslim Women as Citizens in Australia: Perth as a Case Study”, in Y Haddad and J. Smith eds, Muslim Minorities in the West: Visible and Invisible, AltaMira Press, Walnut Creek, CA, pp. 217-232. 